\title{
MASA DEPAN KEBIJAKAN PUBLIK GLOBAL BERBASIS AMERIKA SERIKAT
}

\author{
Jonson Rajagukguk ${ }^{1}$, L. Primawati Degodona ${ }^{2}$ \\ Fakultas Ilmu Sosial dan Ilmu Politik, Universitas HKBP Nommensen \\ jonson.rajagukguk@uhn.ac.id
}

\begin{abstract}
ABSTRAK: Sebagai sebuah bangsa yang kuat secara ilmu pengetahuan dan teknologi Amerika serikat yang disebut sebagai polisi dunia tentu tidaklah berlebihan. Kebijakan publik yang dibuat oleh Amerika Serikat selalu sarat dengan kepentingan ekonominya. Dominasi kawasan yang dibingkai dengan hubungan negara yang sejajar atas dasar hak asasi manusia selalu menjadi pintu masuk bangsa Amerika dalam melakukan politik dominasi. Kebijakan publik yang dibuat oleh Amerika Serikat tentu berorientasi pada kepentingannya. Wajar saja konsep bangsa Amerika Nomor satu oleh pemimpinnya tentu telah membuat kebijakan globalnya selalu berorientasi pada kepentingannya. Dalam percaturan global saat ini bangsa Amerika Serikat selalu membuat kebijakan yang menguntungkan dirinya dalam hal ini kepentingan ekonominya.
\end{abstract}

Kata kunci: Masa Depan, Kebijakan publik global, Kepentingan Ekonomi

ABSTRACT: As a nation that is scientifically and technologically strong, the United States, which is called the world police, is certainly not an exaggeration. Public policies made by the United States are always loaded with economic interests. Regional domination framed by equal state relations on the basis of human rights has always been the entry point for the American nation in carrying out domination politics. Public policy made by the United States is certainly oriented to its interests. Naturally, the concept of the American nation Number one by its leaders has certainly made its global policy always oriented to its interests. In the current global arena, the United States of America always makes policies that benefit itself in this case its economic interests.

Keywords: Future, Global public policy, Economic interest

\section{PENDAHULUAN}

Terpilihnya Joe Biden dan Kamalla harris jadi Presiden dan Wakil Presiden Amerika Serikat memberikan harapan akan masa depan global yang lebih baik. Mengapa tidak, belajar dari pengalaman Donald Trumpt yang sangat kontroversial dengan berbagai kebijakannya yang oleh dunia internasional diangap aneh dan ekstrim, ada harapan baru peran politik global Amerika Serikat melalui kebijakan globalnya bisa menghasilkan sesuatu yang baru untuk semua negara di dunia ini.

Peran negara Amerika Serikat sebagai sebuah negara super power sangat menentukan percaturan politik global. Sebagai sebuah negara dengan sumber daya yang sangat besar dan mumpuni telah membuat negara Amerika Serikat menjadi sebuah negara yang punya peran yang sangat besar. Bagaimana peran kebijakan negara Amerika Serikat dalam pergaulan internasional tentu sangat menentukan masa depan dunia. Tidak bisa dipungkiri kekuatan ekonomi negara Amerika Serikat sebagai tujuan impor dan juga ekspor telah membuat negara ini hadir sebagai negara yang memang punya peran sangat besar dalam menentukan percaturan politik global.

Kebijakan publik global yang terjadi dalam dunia pada era globalisasi ini aktor utamanya adalah negara Amerika Serikat. Sebagai sebuah negara yang pusatnya $\mathrm{PBB}$ dan juga berbagai lembaga -lembaga internasional lainnya 
Amerika Serikat sangat mobil dalam pergaulan internasional. Amerika Serikat tentu punya kepentingan yang sangat besar dalam pergaulan internasional yang membuat masa depan globalisasi menjadi lebih menarik untuk dikaji, khususnya lagi mengenai kebijakan publik yang bersifat global.

Dalam logika hubungan internasional semua bangsa tentu akan mencari keuntungan masing-masing. Penempatan para diplomat suatu negara di negara lain tentu untuk menjaga kepentingannya di negara tersebut. Sekalipun dalam hubungan internasional sering kita lihat, sering kita dengar tagline membangun kerjasama yang jujur atas adasar kepentingan bersama. Itu sebagai norma dan nilai dalam membangun bilateral, multilateral tentu sah-sah saja. Tetapi dalam praktiknya, bagaimana menjaga kepentingan nasional sebuah bangsa akan jadi skala perioritas.

Negara Amerika Serikat sebagai sebuah negara yang sangat kuat secara ekonomi, teknologi, militer tentu akan terus melakukan berbagai upaya agar pengaruh tunggalnya aman. Wajar saja saat ini ada perang dagang yang secara psikologis sangat kita pahami mengapa antara China dan Amerika Serikat saat ini ada ketegangan dan hubungannya selalu tegang yang membuat bangsa -bangsa di dunia ini sangat was-was karena perang dagang dua negara raksasa ini. I

Bagaimana masa depan kebijakan publik global pasca Joe Biden tentu menjadi sebuah pertanyaan yang sangat mendasar. Melalui tulisan ini akan dibahas bagaimana masa depan kebijakan publik global yang mana peran negara Amerika Serikat sangat menetukan menjadi latar belakang dari tulisan ini.

Adapun tujuan dari penulisan ini adalah:

1. Melihat sejauh mana peran kebijakan publik negara Amerika Serikat dalam mempengaruhi kebijakan publik global

2. Menganalisis bagaimana dampak kebijakan Amerika Serikat dalam percaturan politik global.

3. Melihat hubungan Kebijakan publik Amerika Serikat dalam politik intenasional khususnya negara -negara mitra Amerika Serikat.

\section{METODE PENELITIAN}

Metode penelitian makalah ini adalah metode kualitatif dimana penulis menggunakan pedekatan kualitatif deskriptif. Sugiyono (2015) mengatakan metode penelitian kualittaif adalah metode penelitian yang berlandaskan pada filsafat pospositivisme, digunakan untuk meneliti pada kondisi obyek yang alamiah yang hasilnya lebih menekankan makna daripada generalisasi. Dalam tulisan ini penulis memberikan paparan mengenai dampak kebijakan publik negara Amerika Serikat dalam mmepengaruhi kebijakan publik global Amerika Serikat.

\section{PEMBAHASAN}

Berbicara mengenai kebijakan publik dewasa ini, istilah kebijakan memang lebih sering dipergunakan dalam konteks tindakan-tindakan atau kegiatan yang dilakukan para aktor dan institusi-institusi pemerintahan, serta perilaku negara pada umumnya (United Nation, 1975; Nevil Johnson, 1980). ${ }^{1}$ Dalam kaitan itu, mudah dipahami jika konsep kebijakan itu kemudian sering berkonotasi, serta 
membawa konsekuensi politis, dari sinilah lantas diberi makna sebagai tindakantindakan politik (political actions). Makna kebijakan sebagaimana kita kemukakan tadi akan semakin jelas bila kita ikuti pandangan seorang ilmuan politik Carl Friedrich, saat ia menyatakan bahwa kebijakan itu ialah suatu tindakan yang mengarah pada tujuan yang diusulkan oleh seseorang, kelompok, atau pemerintah dalam lingkungan tertentu sehubung dengan adanya hambatanhambatan tertentu seraya mencari peluang-peluang untuk mencapai tujuan atau mewujudkan sasaran yang diinginkan.

Apa yang baru saja dikemukakan oleh frederich di atas akan semakin jelas jika kita pertegas lagi dengan pendapat knoepfel dan kawan-kawan (2007) saat mereka mengartikan kebijakan sebagai :

"A series of decisions pr activities resulting from structured and recurred interactions between different actors, both public and private, who are involved in various different ways in emergence, identification and resolution of problem defined politically as a public one" (serangkaian keputusan atau tindakantindakan sebagai akibat dari interaksi terstruktur dan berulang diantara berbagai aktor, baik publik/pemerintah maupun privat/swasta yang terlibat berbagai cara merespon, mengidentifikasi, dan memecahkan suatu masalah yang secara politis didefinisikan sebagai masalah publik).

Kalau konsep-konsep yang disodorkan frederich maupun knoepfel dan kawan-kawan tersebut kita cermati, kita akan memperoleh sebuah pemahaman baru sebagai berikut :

a. Bahwa fokus perhatian kita saat mempelajari analisis kebijakan publik itu lebih pada apa yang nyata dilakukan oleh pemerintah, dan bukan sekedar pada apa yang nyata dipikirkan atau ingin dilakukan.

b. Harus kita bedakan secara tegas antara kebijakan (policy) dan keputusan (decision), dimana yang disebut pertama itu mengandung arti adanya pemilihan di antara sejumlah alternatif yang (dianggap) tersedia.

c. Jika kita telusuri semua kebijakan secara normatif bersifat problem solving (pemecahan masalah). Artinya, setiap kebijakan sejatinya dimaksudkan untuk memecahkan atau setidaknya mengurai kerumitan masalah publik, yakni masalah-masalah kolektif yang sempat teridentifikasi dan berhasil masuk agenda pemerintah (govermental agenda). Dengan demikian, kebijakan apapun, meminjam kata-kata knoepfel dan kawan-kawan (2007:21) sebenarnya mencerminkan respon/ tangggapan sistem politik dan administrasi terhadap sebuah realita sosial, yang secara politis di anggap tak bisa lagi di toleransi

Smith dan larimer (2009) menyatakan "there is not a field of public studies, there are fields-plurals-of public policy studies" (ini bukan tentang bidang studi tentang kebijakan publik, ada bidang-jamak-dari studi kebijakan ${ }^{2}$. Berdasarkan perspektif ini baik konten maupun konteks kebijakan publik itu akan selalu di anggap sebagai bersifat plural, dan karena itu masalah-masalah kebijakan (policy problem) pun sebagai sebuah academic enquiry (permintaan akademik) tidak hanya menjadi minat para ahli disiplin ilmu tertentu yang mempelajari atau mendekatinya secara monodisiplin. Itu pula sebabnya, sudah sejak lama masalahmasalah kebijakan itu menjadi arena pergumulan dari para ahli dari bermacam disiplin ilmu sosial yang sengaja mengorientasikan diri pada kebijakan (policy 
oriented) dan yang pelajari atau menelitinya secara interdisplin (interdiciplinary approach.).

W.I. Jenkis (1978:15), merumuskan kebijakam publik sebagai serangkaian keputusan yang saling berkaitan yang diambil oleh seorang aktor politik atau sekelompok aktor, berkenaan dengan tujuan yang telah dipilih beserta cara-cara mencapainya dalam suatu situasi. Keputusan-keputusan itu pada prinsipnya masih berada dalam batas-batas kewenangan kekuasaan dari pada aktor tersebut.

Menurut Young dan Quinn dalam (Edi Suharto 2005:44), kebijakan publik adalah sebuah keputusan untuk melakukan atau tidak melakukan sesuatu. Kebijakan publik pada umumnya merupakan tindakan kolektif untuk memecahkan masalah sosial. Menurut Lemieux dalam (Solichin Abdul Wahab 2012:15), kebijakan publik adalah produk aktivitas-aktivitas yang dimaksudkan untuk memecahkan masalah-masalah publik yang terjadi di lingkungan tertentu yang dilakukan oleh aktor-aktor politik yang hubungannya terstruktur. Keseluruhan proses aktivitas itu berlangsung sepanjang waktu.

Menurut Chief J O Udoji dalam (Solichin Abdul Wahab 2012:15), kebijakan publik adalah suatu tindakan bersanksi yang mengarah pada suatu tujuan tertentu yang saling berkaitan dan memengaruhi sebagian besar warga masyarakat. Menurut Wilson dalam (Solichin Abdul Wahab 2012:13), kebijakan publik adalah tindakan-tindakan, tujuan-tujuan, dan pernyataanpernyataan pemerintah mengenai masalah-masalah tertentu, langkah- langkah yang telah/sedang diambil (atau gagal diambil) untuk diimplementasikan, dan penjelasan-penjelasan yang diberikan oleh mereka mengenai apa yang telah terjadi (atau tidak terjadi). Menurut Leo Agustino (2008:8) kebijakan publik merupakan keputusan politik yang dikembangkan oleh badan dan pejabat pemerintah.

Menurut Dye dalam (Arifin Tahir 2014:20), Kebijakan public adalah apapun yang dipilih oleh pemerintah untuk dilakukan atau tidak dilakukan.

Pakar Prancis, Lemieux (1995:7) merumuskan kebijakan publik sebagai berikut :"The product of activities aimed at the resolution of public problem in enviroment by political actors whose relationship are structured. The entire process evolves over time" (produk aktivitas-aktivitas yang dimaksudkan untuk memecahkan masalah-masalah publik yang terjadi di lingkungan tertentu yang dilakukan oleh aktor-aktor politik yang hubungannya terstruktur. Keseluruhan proses aktivitas itu berlangsung sepanjang waktu. Dari perbincangan tentang definisi kebijakan publik di atas, kini kita dapat menyadari bahwa semua pembutan kebijakan publik (policy making) itu akan selalu melibatkan pemerintah dengan cara tertentu.

Dari pengertian di atas kebiajkan publik itu juga menyangkut konsep apa yang dilakukan oleh negara. Berbagai kebijakan publik global yang dilakukan oleh negara Amerika Serikat adalah kebijakan yang diperuntukkan untuk mempengaruhi negara-negara di dunia. Bagaimana kebijakan publik negara Amerika Serikat kedepan oleh Presiden Joe Biden tentu jadi sebuah pertaruhan dalam rangka menciptakan tatanan global yang lebih baik untuk menumbuhkan interaksi negara yang saling menghormati.

Presiden Amerika Serikat yang baru Joe Biden dan Wakilnya Kamalla Harris telah dilantik. Proses suksesi kepemimpinan di Amerika Serikat ini terbilang kurang demokratis karena ulah dari Donald Trumpt dan pendukungnya yang tidak menunjukkan karakter substansi demokrasi. Trumpt masih sulit "move 
on" dan tidak mau mengakui kekalahannya dengan tulus dan iklas. Walalupun demikian, Joe Biden dan Kamalla Harris akan jadi Presiden USA Dan Wakil Presiden USA dengan berbagai ekpektasi dari semua negara-negara dunia. Tidak bisa kita pungkiri, sebagai negara adidaya dan negara super power yang didukung oleh kekuatan teknologi, finansial dan nilai demokrasi Presiden terpilih USA juga merupakan presiden warga dunia. Masalahnya, bagaimana Joe Biden dan Kamala Harris mampu menampilkan kepemimpinan yang visioner, merangkul semua negara, mengedepankan kesetaraan global, mendukung keadilan global sehingga wajah globalisasi akan lebih manusiawi.

Dunia harus dibangun atas dasar kebersamaan dan kesetaraan dengan catatan bahwa semua negara-negara di dunia ahrus saling mendukung tanpa ada politik dominasi. Dominasi itu harus ditanggalkan diganti dengan kemitraan global yang sejajar sehingga semua negara bisa saling berdampingan sekalipun nilai dan budaya yang dianut berbeda. Bagaimana masa depan dunia yang lebih manusiawi? Pertanyaan ini sangatlah mendasar dan menentukan masa depan global ditengah arus kemajuan yang sangat luar biasa saat ini.

Sekali lagi, harapan akan perubahan yang lebih baik dan menjadikan USA sebagai sebuah negara yang jadi role model kini ada di pundak Joe Biden bersama wakilnya Kamala Harris yang merupakan representasi dari keberagaman (representation of diversity) sebuah bangsa yang harus mendapat pengakuan. Tidak bisa dipungkiri politik Amerika Serikat selalu berorientasi pada pasar (keuntungan). Kerjasama yang dibangun dengan berbagai dalih kemitraan yang sejajar, hak asasi manusia, kesetaraan semua negara hanyalah pintu masuk untuk membawa kepentingan ekonomi. Artinya, "profit oriented" atau kepentingan ekonomi selalu menjadi skala perioritasnya. Peran itu memang bisa dimainkan karena sumber daya bangsa Amerika yang sangat mendukung untuk itu. Artinya, agenda Amerikanisasi sebagai sebuah agenda terselubung (hidden agenda) tidak bisa dipungkiri. Mengamerikakan dunia dibalik diplomasi ekonomi dilakukan dengan berbagai strategi.

Mampukah Joe Biden mencegah dan mengeliminir Amerikanisasi dunia (mengamerikakan dunia) di tengah proses globalisasi yang berpihak pada negaranegara kuat saat ini? Bisakah Amerika Serikat jadi saluran berkat, mendukung kemajuan bersama dengan jujur, menularkan efek yang lebih humanis bagi bangsa lain? Atau bisakah Amerika jadi mitra sejajar dan strategis bagi bangsa -bangsa di dunia pasca terpilihnya Joe Biden sebagai Presiden USA ke -46? Rentetan pertanyaan ini muncul pada Joe Biden sebagai sebuah ekspekstasi masyarakat global kepadanya.

Mau tidak mau, Joe Biden adalah Presiden dunia secara "de facto" karena pengaruh USA terhadap dunia ini sangat besar. Kekuatan ekonomi, penguasaan IPTEK mumpuni yang sangat hebat, punya universitas yang bereputasi wahid, kiblat pengetahuan, pusat PBB dan organisasi internasional lainnya berada di USA merupakan modal Amerika Serikat untuk jadi pemimpin dunia. Fakta ini tidak bisa kita abaikan. Hanya saja bagaimana Amerika Serikat bisa mengelola semua modal ini untuk membangun masa depan globalisasi yang sangat manusiawi sehingga globalisasi apapun itu bisa bermanfaat untuk semua warga dunia.

Membangun tatanan dunia baru yang harmonis, tanpa intervensi, tanpa nafsu mengendalikan (without lust to control), semangat menghormati kedaulatan (respect for sovereignty) negara adalah nilai peradaban yang musti dipelihara. 
Artinya, semua negara dunia harus bergandengan tangan secara damai untuk menciptakan tatanan dan hubungan yang harmonis atas dasar spirit persaudaraan global. Dengan demikian, kehidupan global yang damai dan saling bersimbiosis (saling menguntungkan) bisa diwujudkan dengan baik.

Hanya saja dalam fakta Keamerikaan bangsa Amerika sendiri tidak bisa kita pungkiri dengan slogan "AMERICA number one" sangatlah mengusik. Sebagaimana yang kita lihat penilaian orang terhadap Amerika sebagai bangsa yang melakukan "ekspansi" (penjajahan gaya baru) telah menjadi "axioma" dan harus diterima oleh semua negara bangsa (nation state) di dunia. Boleh dikatakan Amerika selalu menganggap bangsa-bangsa dunia ketiga dengan sebelah mata. Amerika yang didukung oleh kemampuan penguasaan ilmu pengetahuan dan teknologi mutahir yang tiada "bertepi" telah hadir menjadi bangsa yang "super power" dan mempunyai peran sebagai polisi dunia yang sangat menentukan kebijakan global.

Ditengah-tengah kedigdayaan bangsa Amerika, fenomena globalisasi muncul sebagai peluang sekaligus nestapa bagi negara-negara bangsa (lemah secara ekonomi danIPTEK) di dunia. Dengan prinsip "We One The World" telah menggiring dunia menjadi sebuah desa (global village), jarak dan waktu bukan lagi menjadi persoalan. Hukum globalisasi biasanya, yang kuat makin kuat (kuat modal dan SDM) dan yang lemah makin lemah (lemah modal dan SDM). Futurist Alvlin Toffler dalam bukunya "Futur Shock" (1970) mengatakan, apa yang dilakukan di benua lain hari ini, mempunyai dampak esok pagi disini. Contohnya, hasil pilpres Amerika dapat seketika dilihat pada FB, twitter, atau media online. Perubahan paradigma yang dipicu oleh arus globalisasi tersebut mondorong berkembangnya peradaban baru untuk mengisi kebutuhan manusia dalam menemukan solusi dan alternatif guna meningkatkan kualitas hidup manusia. Pada saat manusia dibelahan negara-negara dunia ketiga ingin menemukannya, Amerika telah hadir sebagai kekuatan yang tidak tertandingi dan harus tunduk pada kebijakan mereka. Inilah persoalan politik yang dihadapi oleh negara-negara bangsa dibelahan dunia ketiga.

Dalam konteks ini istilah revitalisasi dan reformasi sering digunakan penguasa untuk mengidentifikasi adanya proses perubahan kearah sesuatu sesuai kehidupan manusia yang lebih baik dari sebelumnya. Alvlin Toffler mengigatkan kita, bahwa masyarakat dunia sedang memasuki peradaban gelombang ketiga "The Third Wave", yaitu peradaban pasca industri yang ditandai dengan kemajuan yang sangat pesat dalam teknologi informasi. Peradaban gelombang ketiga ini dapat disebut sebagai era teknologi informasi, yang menjadi salah satu karakter utama arus globalisasi.

Dapat dikatakan bahwa globalisasi dewasa ini, telah membawa kecenderungan makin kuatnya peranan politik dan militer dalam mengatur dinamika kehidupan sosial masyarakat. Secara kasat mata dapat kita lihat, politik dan militer Amerika telah hadir sebagai penguasa tunggal dunia yang selalu hadir dalam setiap konflik internasional. Dalam hal ini berlaku prinsip politik "standar ganda" (double standard), selagi masih menguntungkan Amerika akan berjuang habis-habisan tanpa melihat mana yang benar dan mana yang salah. Kedepan politik standard ganda ini harus dihilangkan dalam membangun tatanan dunia baru yang lebih manusiawi.

Tetapi perlu juga kita pahami, dalam proses globalisasi negara-negara sedang berkembang juga perlu dan harus meningkatkan kualitas dirinya. Tidak 
ada kata terlambat untuk belajar dan menjadi bijak (Better late than never), itulah yang harus dilakukan oleh setiap negara bangsa. Sebagai negara bangsa dibelahan dunia ketiga (nation state) yang baru muncul pada abad 20, timbul pertanyaan yang sangat menggelitik, apa yang telah berhasil dilakukan? Mengingat tantangan yang akan dihadapi semakin besar dan kompleks. Kompleksitas masalah (problem complex) yang akan dihadapi negara-negara bangsa (nation state) bukan lagi dalam konteks nasional, tetapi dalam konteks global. Globalisasi sebagai cermin dari abad 21 atau millennium ketiga telah mengundang tantangan bagi setiap negara bangsa (nation state) di dunia ini.

Terlepas dari itu, dengan diberlakukannya pasar bebas diseluruh dunia melalui bendera WTO, dapat dipastikan bahwa banyak negara bangsa apalagi negara-negara dunia ketiga yang tidak siap. Masalah sekarang adalah situasi perekonomian negara-negara dunia ketiga belum pada tingkat kemapaman, bahkan negara-negara dunia ketiga masih berjuang menghadapi krisis ekonomi apalagi di era pandemi covid-19 ini. Jadi boleh dikatakan negara-negara berkembang masih dalam transisi ekonomi menuju tingkat kemapanan sebagaimana yang dikatakan oleh J. Rostow. Di pihak lain, pemberlakuan pasar bebas membuka gelombang kran globalisasi dengan berbagai dampak (effect) yang ditimbulkan. Ekspansi pasar (market expansion) yang dilakukan oleh negara maju cenderung melakukan eksploitasi pada sumber daya alam negara berkembang. Akibatnya, terjadi ketimpangan sosial yang sangat besar dan jadi potensi konflik antara korporasi dan masyarakat lokal di sebuah negara karena aktivitas ekonomi yang tidak berpihak kepada negara berkembang. Globalisasi ekonomi lagi-lagi jadi sebuah bumerang (a boomerang) pada masyarakat negara berkembang, termasuk negara kita saat ini.

Kini, dengan terpilihnya Joe Biden sebagai Presien USA ke- 46 yang akan berusaha memperbaiki internal negaranya dengan berbagai kebijakan yang akan diambil, harapan kita kebijakan internalnya adalah kebijakan yang membawa peruntungan (policy speranza) juga bagi bangsa yang lain. Kita sepakat dengan patron, "kalau Amerika kuat dan sejahtera, maka negara lain juga akan meraskan dampak positifnya. Dalam artian yang sederhana, kesejahteraan Amerika juga kesejahteraan masyarakat dunia (welfare of the people of the world) lainnya. Saat ini krisis ekonomi juga sedang dihadapi oleh Amerika. Bahkan berbagai konflik sosial antara warga kulit putih dan hitam juga sangat terasa. Kita sangat mengharapkan internal Amerika itu segera berakhir. Terlepas dari adanya berbagai indikator positif (the positive sentiment) menguatnya pasar saham dalam merespon Biden, itu hanya temporer. Pada akhinya, kebijakan Biden yang diambil untuk kepentingan yang lebih besar (greater interest) bisa memulihkan kepercayaan pasar (restore market confidence).

\section{KESIMPULAN}

Harapan kebijakan publik global yang dilakukan oleh Presiden baru Joe Biden sangat kita harapkan menjadi kebijakan publik yang mampu menciptakan tatanan dunia baru yang lebih baik. Mampukah Joe Biden memimpin Amerika Serikat sebagai bangsa yang bisa jadi saluran berkat bagi bangsa lain dengan membawa Amerika sebagai bangsa pengayom, bangsa pelindung bagi semua negara dunia, bangsa yang menularkan efek positif (nation that transmits positive effects), bangsa yang jadi inspirator, bangsa yang jadi panutan (role model), 
sehingga masa depan globalisasi itu lebih menusiawi di era revolusi industri 4.0 ini? Semoga saja Joe Biden bisa menjadi pemimpin global yang membawa peradaban global yang baru dengan berbagai kebijakan yang humanis, populis, dan orientasi kepentingan bersama secara global atas dasar nilai kesetaraan dan kesejajaran. Optimisme untuk itu harus dibangun. Biden "effect" akan menentukan masa depan globalisasi yang lebih manusiawi, dan bukan hanya mewujudkan Amerikanisasi saja.

\section{DAFTAR PUSTAKA}

Abdul Wahab, Solichin (1997) Analisis Kebijaksanaan : Dari Formulasi keimplementasi Kebijaksanaan Negara. Penerbit PT Bumi Aksara Jakarta.

(1998) Analisis Kebijakan Publik : Teori dan Aplikasinya. Penerbit Fakultas Ilmu Administrasi Univ. Brawijaya Semarang.

Christopher Larimer, dan Smith, Kevin B. r, The Public Policy Theory Primer, 2009

Dunn, Willian.N (1981) Public Policy Analysis : An Introduction. Prentice-

Hal,Inc., Englewood Cliffs,N.J.07632. USA.
----, (1992) Analisis Kebijaksanaan Publik. Penyadur: Muhajir Darwis. Penerbit PT. Hanindita Yogyakarta.

Diterjemahkan oleh: Samodra Wibawa, dkk Penerbit Gajah
Mada University.

Diterjemlahkan oleh Samodra Wibawa,dkk. Penerbit Gajah Mada University Press Yogyakarta.

Dye, Thomas R. (1987) Understanding Public Policy. Prentice- Hall, INC., Englewood Cliffs, NJ. USA. -, (1976) Policy Analysis : What Governments Do, Why They Do It, and What Difference it Makes. The University of Alabama Press.

Jenkis, WI, Author of For Policy Analysis, 2013

Pratikno, Sketsa Kebijakan Desentralisasi di Indonesia, Averrpes Press, Malang, 2005

Salam, Setyawan Darma, Manajemen Pemerintahan di Indonesia, Penerbit Djambatan, Jakarta, 2007.

Sarundajang, SH, Arus Balik Kekuasaan Pusat ke Daerah, Pustaka Pelajar, 2002. Tangkilisan, Hesel Nogi, Manajemen Publik, PT. Gramedia Pustaka Utama, 2005. Suiyono, Metode Penelitian Kualitatif dan Kuantitatif, Alfabeta, Bandung, 2007 Harian Waspada, Amerikanisasi Pasca Biden, Februari 2021 